\title{
ACADS wt Allele
}

National Cancer Institute

\section{Source}

National Cancer Institute. ACADS wt Allele. NCI Thesaurus. Code C82872.

Human ACADS wild-type allele is located within 12q22-qter and is approximately $14 \mathrm{~kb}$ in length. This allele, which encodes short-chain specific acyl-CoA dehydrogenase,

mitochondrial protein, is involved in lipid oxidation. Mutations in the gene are associated with short-chain acyl-CoA dehydrogenase deficiency. 